\title{
Pneumatikus megfogóval szerelt többtengelyes manipulátor irányítása PLC -vel
}

\author{
Nagy Ádám \\ Mechatronikai Tanszék \\ Debreceni Egyetem, Müszaki Kar \\ Debrecen, Magyarország \\ nagyadi21@gmail.com
}

\author{
Dr. Tóth János \\ Mechatronikai Tanszék \\ Debreceni Egyetem, Müszaki Kar \\ Debrecen, Magyarország \\ tothjanos@eng.unideb.hu
}

\author{
Dr. habil. Husi Géza \\ Mechatronikai Tanszék \\ Debreceni Egyetem, Müszaki Kar \\ Debrecen, Magyarország \\ husigeza@eng.unideb.hu
}

Projekt feladat során a többtengelyes manipulátor müködése lett megvizsgálva. A feladat megoldása Bosch PLC (Programmable Logic Control) HMI (Human Machine Interface) felhasználásával, ST (Structured Text) programozási nyelv segítségével. A manipulátor egy gyártási folyamatban történő alkatrész mozgást valósít meg.

Kulcsszavak: PLC, HMI, Léptetö motor

\section{BEVEZETŐ}

Feladat egy többtengelyes manipulátor vezérlése PLC és HMI felhasználásával, melyet a tanszéken található Rexroth elektromos többtengelyes mozgató rendszerrel valósult meg.

$\mathrm{Az}$ „X” és „,Y” tengelyek mozgatása ipari léptetőmotorral történik. A „Z” irányban történő mozgatását pedig pneumatikus munkahenger valósítja meg. A munkahenger alsó pontjára egy szintén pneumatikus megfogó van felszerelve, ami a mozgatni kívánt tárgyak megfogását szolgálja. A feladat célja, hogy a különböző mozgásokat PLC segítségével irányítsa, miközben a PLC és a HMI keresztül kommunikálnak egymással. A folyamat rögzített lépései után a munkaasztalon elhelyezett „,elkészült" munkadarabot ki kell emelni a többtengelyes manipulátorból, hogy folytatódni tudjon a meghatározott sorrendủ munka ciklus.

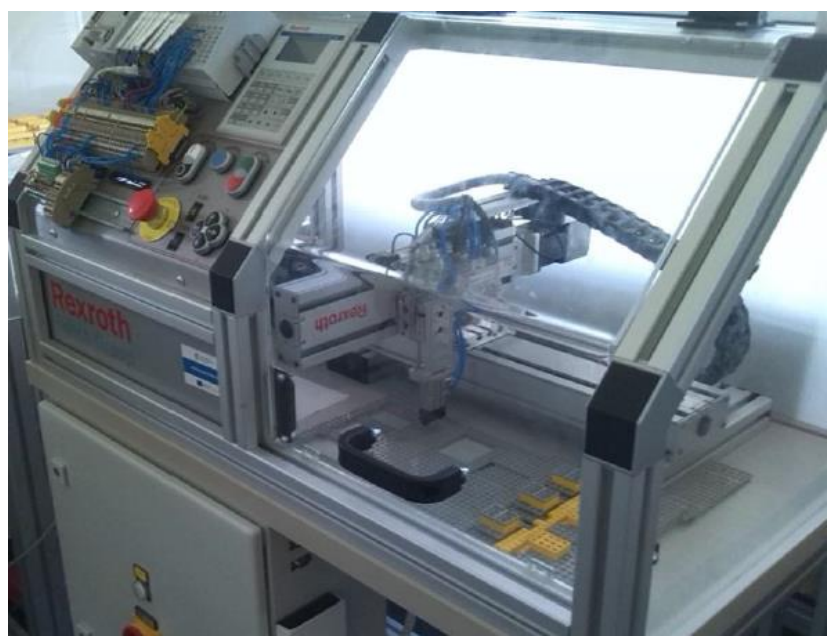

\section{FELADAT MENETE}

A projekt első lépése a manipulátor irányításához szükséges eszközöket, valamint azok működését megismerni. A következő lépésben a léptetőmotorok felprogramozásához szükséges kommunikációt kell megvalósítani. A motorok kívánt pozícióit és az azokhoz tartozó sebességet kellett beállítani a léptető motoroknak. Később ezeket a pozíciókat PLC felhasználásával lehetett elérni. Ezt követően a PC és PLC közötti kommunikációt kell megvalósítani ahhoz, hogy a kívánt müveletek végrehajtásához szükséges programkód feltölthetővé váljon a PLC-re. A PLC az „X”, ,Y” valamint a „Z” tengely mozgást és megfogás állapotait irányítja, így ezeket a lépéseket kell automatizálni. Majd ezt követően a PC és HMI közötti kommunikáció megvalósítása a cél. A HMI programozásához szükség van a PLC által használt változók beolvasására. Ehhez a PLC programozói szoftveréből kellett kimenteni a változókat egy fájlba kiíratni, majd azt beolvasni a HMI programozásához.

\section{MANIPULÁTORON TALÁLHATÓ ESZKÖZÖK}

A Rexroth manipulátoron megtalálható eszközök segítenek abban, hogy a manipulátor kézi üzemben és automatikusan is irányítható legyen. Kézi üzemmódban történő használat során nyomógombok segítségével lehet a léptető motorokat lassú mozgásokkal működtetni. a pneumatikus „Z” irányú mozgást tesztpanel segítségével lehet mozgatni.
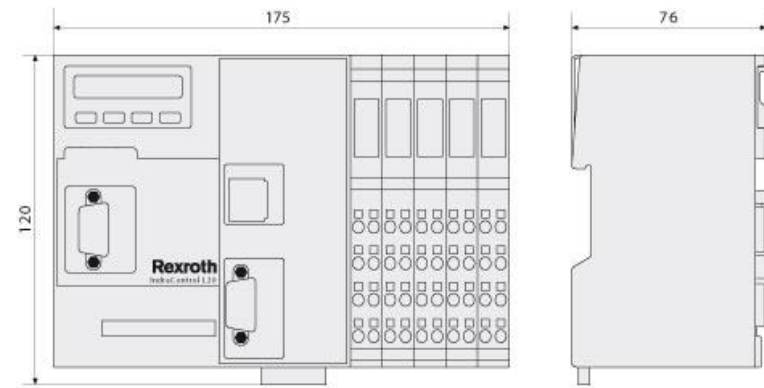

1. ábra: Bosch Rexroth többtengelyes manipulátor 
2. ábra: $L 20$ PLC

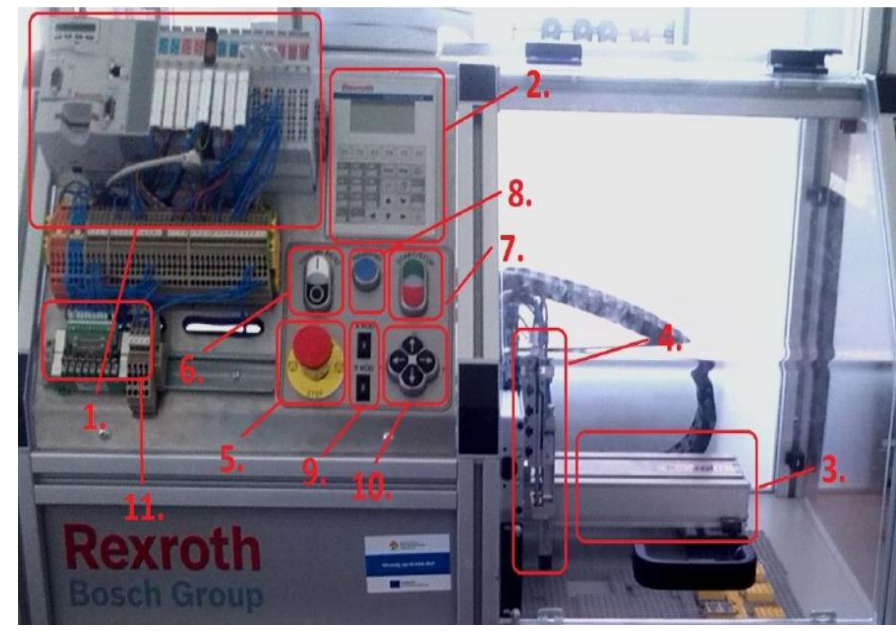

3.ábra: Manipulátor fö elemei

1. Rexroth PLC L20,

2. VCP-05 HMI,

3. Schneider léptetö motoros hajtás,

4. Rexroth pneumatika,

5. Vészstop,

6. Vezérlés be/ki,

7. Start/stop gomb,

8. Hibatörlés,

9. Kód kerekek „X” és „Y” tengelyekhez,

10. JOG mód,

11. Tesztpanel.

A Rexroth PLC L20 alapvetően rendelkezik $8 \mathrm{db}$ digitális bemenet és $8 \mathrm{db}$ digitális kimenettel. Ezen felül R-IB IL 24 DI 32 bemeneti bővítő modullal és R-IB IL 24 DO 32 kimeneti bővítő modullal lett ellátva.

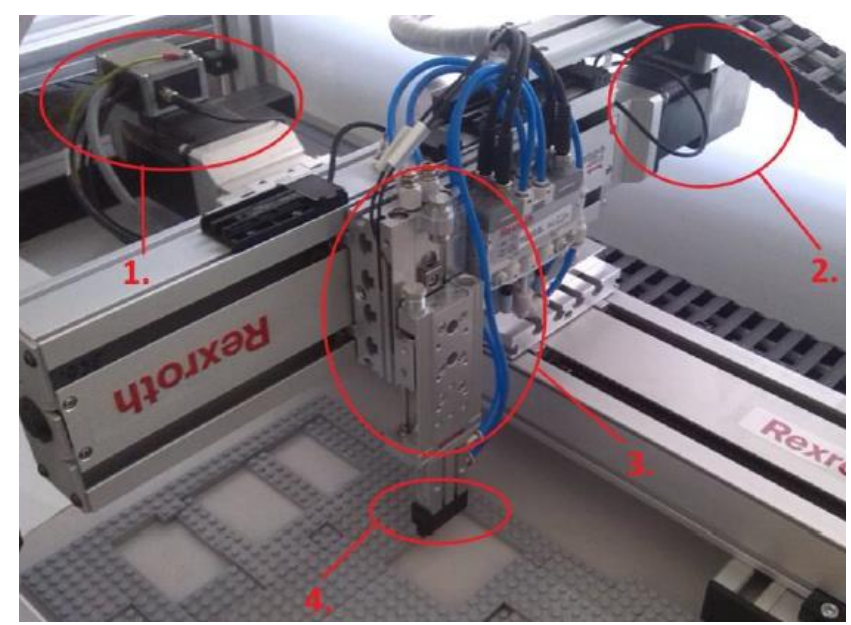

4.ábra: Manipulátor tengelyek

1. „X” tengelyt mozgató léptetőmotor,

2. „Y” tengelyt mozgató léptetőmotor,
3. „Z" tengelyt mozgató pneumatikus munkahenger,

4. Pneumatikus megfogó.

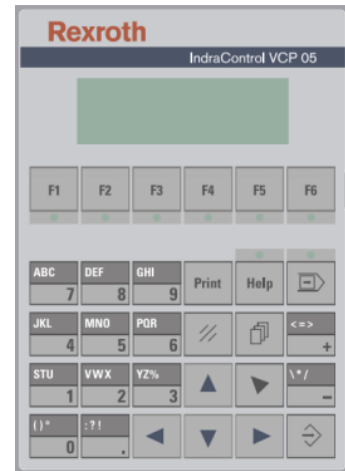

5.ábra: VCP-05 HMI

A ,Z” tengelyt mozgató pneumatikus munkahengert és megfogó szerkezet munkahengerét egy elektromosan elővezérelt 5/2-es bistabil szeleppel lett irányítva.

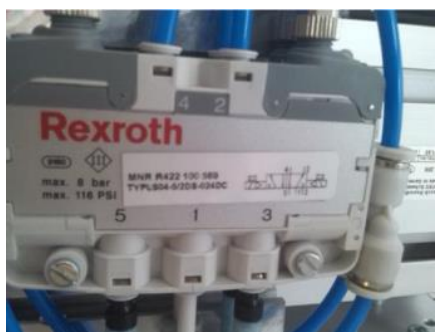

6.ábra: Elektromos müködtetésü, 5/2-es, rugó visszatéritéses pneumatikus útváltószelep

A manipulátor pneumatikus eszközeinek biztosítani kell a megfelelő sürített levegő előkészítését, előállítását.

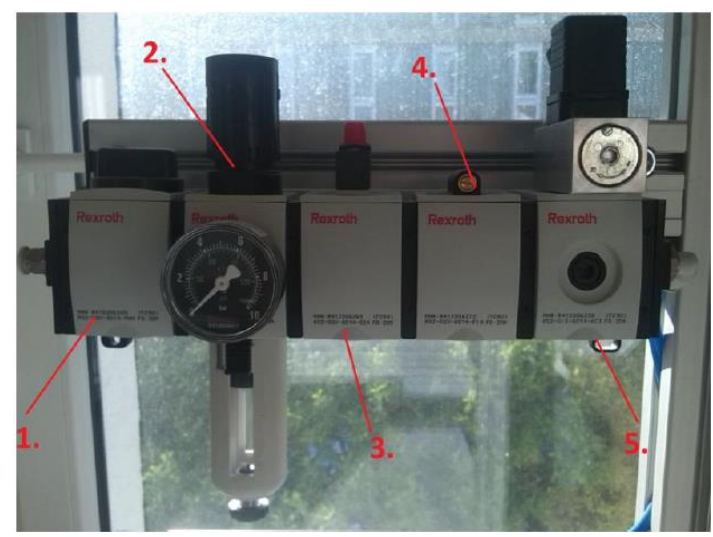

7.ábra: Levegö elökészitö egység

1. Pneumatikus fökapcsoló,

2. Nyomásszabályozó, nyomásmérővel és kondenzvíz leválasztóval, 
3. Elektromos elzáró szelep,

4. Mechanikus nyomásszabályzó,

5. Nyomáskapcsoló.

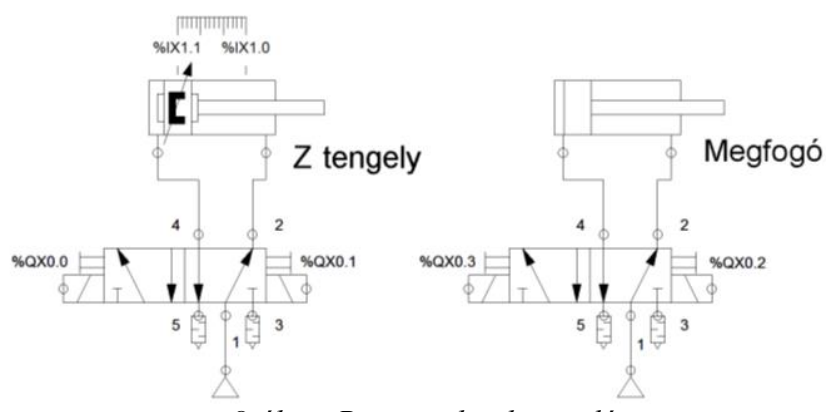

8. ábra: Pneumatikus kapcsolási rajz

\section{PROJEKTFELADAT MEGVALÓSÍTÁSA}

A programkódot úgy kellett elkészíteni, hogy szükségtelen, felesleges mozgásokat ne végezzen a manipulátor. A szimulált gyártási folyamatnál az feltöltési és leürítési lépésnél jelenhetne meg. Az indítás során még a munkaállomásokon nincsenek alkatrészek így az egyes állomásokból történő áthelyezés nem megvalósítható és időveszteséget vinne a rendszerbe, ha a gép üresjáratban müködik. A programozás során ezt úgy lett megoldva, hogy amíg minden munkaállomást fel nem tölt a manipulátor addig, olyan programrész indul el, ami csak egyszer fut le (amíg van üres megmunkáló állomás). A folyamat leürítésénél hasonló folyamatot valósít meg a gép (nem szállít be újabb nyersanyagot a manipulátor).

A manipulátor felhasználásával egy gyártási folyamatban történő munkadarab mozgatása valósult meg. Minden egyes alkatrész gyártás során három munkafázison halad keresztül. A nyersanyag ejtő tárból kerül a nyersanyag tárolóba. A manipulátor ebből a pozícióból emeli ki a munkadarabot és szállítja a különböző munkaterületekre, majd a készterméket a gyüjtőtárba helyezi el.

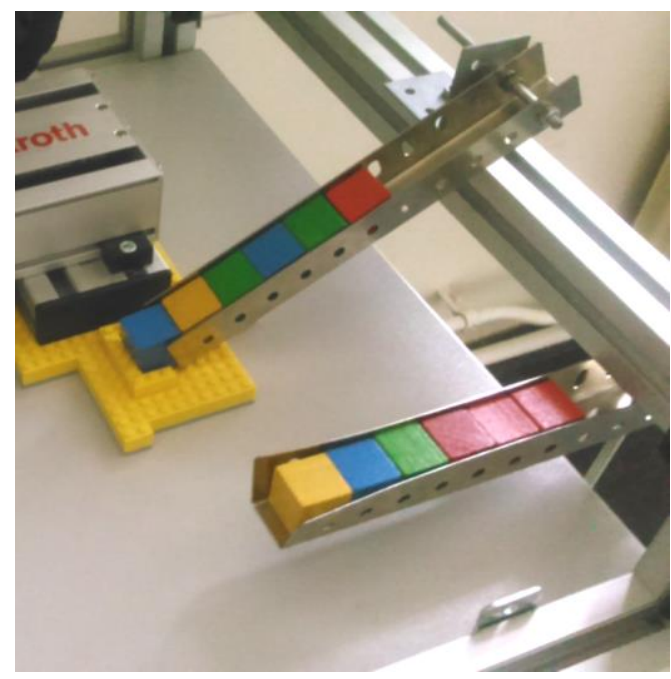

\section{9. ábra: A kibövitett ejtö és gyüjtőtár}

A gyártósor programozásánál különböző üzemmódok lettek megvalósítva. A kezelő választhat automata és kézi üzemmódok közül. Automata üzemmód esetén a gyártási folyamat elindul és folyamatos gyártást valósít meg emberi beavatkozás nélkül. Automata üzemben lehetőség van arra, hogy HMI felületén megadásra kerüljön a gyártani kívánt darabszám. Amikor elérte a megadott értéket a gép leáll. HMI felületén folyamatosan követhető a késztermék száma. A folyamat leállításához az üzem vége parancsot kell kiadni HMI-n keresztül a PLC-nek. Ebben az esetben a gép a megkezdett munkadarabokat még elkészíti, de újabb nyersanyagot már nem indít el a folyamatban

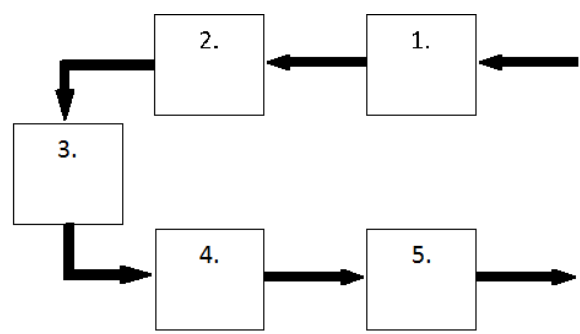

10. ábra: Munkaterület és alkatrész mozgás vázlata

1. ejtő tár (nyersanyag),

2. első megmunkáló állomás,

3. második megmunkáló állomás,

4. harmadik megmunkáló állomás,

5. gyüjtőtár ( kész munkadarab).

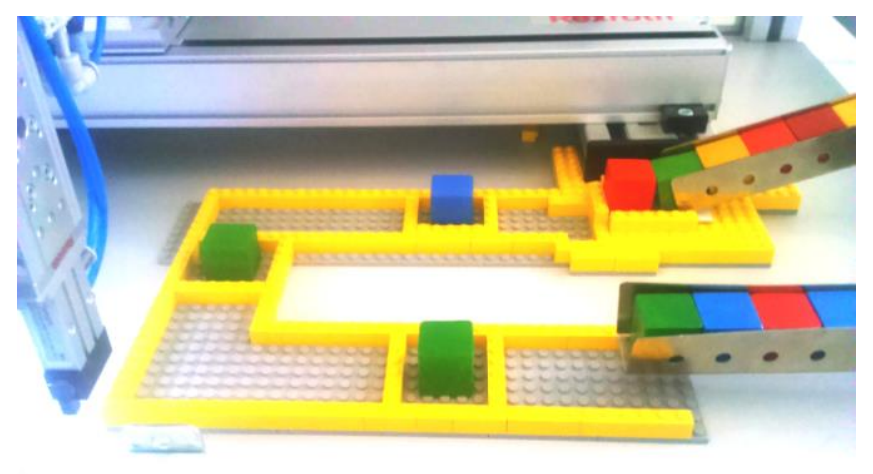

11. ábra: A megvalósitott munkaterület

Automata üzemmódban a manipulátor önmüködően helyezi át az alkatrészeket az elkészített programkód alapján. Kézi üzemmódban a HMI segítségével a kezelő adja meg azt a pozíciót ahová a manipulátort irányítani kell. A motorok pozícióba futását követően a „Z” irányú mozgásokat és a megfogást kapcsolók segítségével lett megvalósítva. Erre azért volt szükség, mert a HMI kijelzőjének kis mérete miatt egy képernyőn nem fértek volna el a „Z” tengelyt mozgató parancsok.

Automata és kézi irányítás esetén is a számítógép monitorján a föbb állapotok lekövethetőek vizuális formában. Ehhez az elkészített vizualizációs felület nyújt 
információt. A megfogó szerkezet felfele illetve lefele mozgását egy munkahenger modellezi le. A mozgás végét a „Z” tengelyre szerelt végállás érzékelők állítják meg. Az egyes munkaállomások feltöltését a szimulációban zöld szín jelzi. Ha az alkatrész kiemelése megtörténik akkor a szimulációban szürkére vált vissza az adott munkaállomást jelképező téglalap.

F1: AUTOMATA ÜZEM

F2: KÉZI ÜZEM

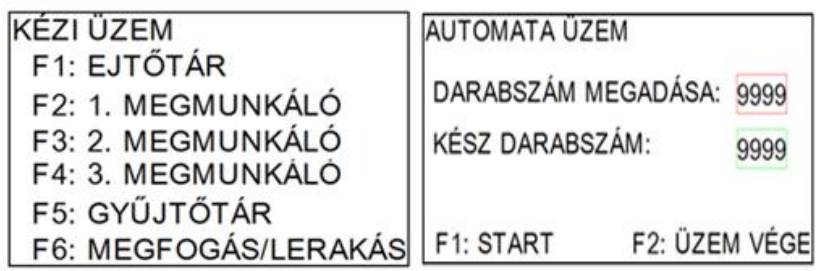

12. ábra: HMI-re általam készített felületek
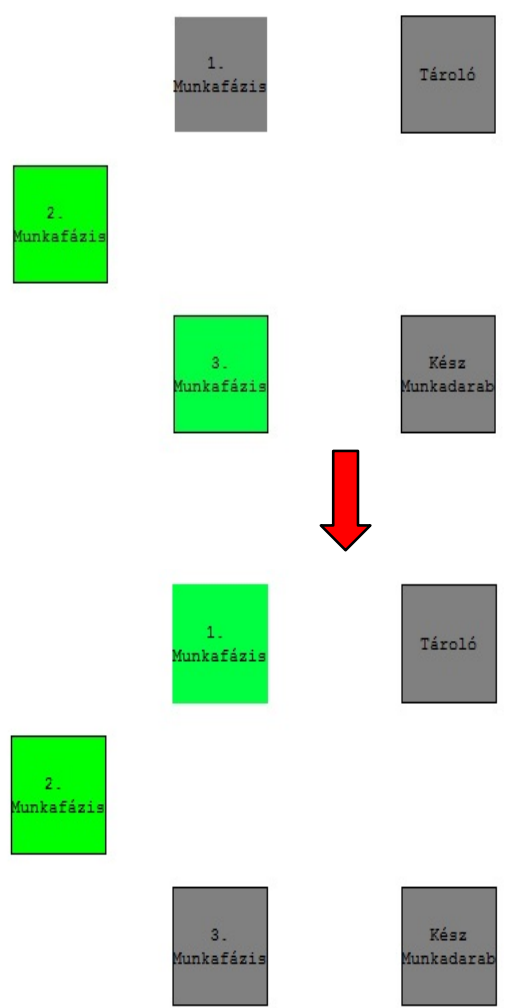

13. ábra: Vizualizáció két különbözö állapotban

\section{TOVÁBBFEJLESZTÉSI LEHETÖSÉGEK}

A jelenlegi rendszerben kevés érzékelő szolgáltat jelet az aktuális állapotokról. Ahhoz, hogy az Ipar 4.0 irányelveknek jobban megfelelő irányítást lehessen megvalósítani, szükséges lenne a munkadarabok érzékelése a tárolókban. Az irányító egységnek nincs pontos információja arról, hogy a nyersanyagtároló mikor ürül ki. Ilyenkor hibás müködés léphet fel, mivel a program tovább parancsokat ad ki a irányítja a manipulátor számára. Nyersanyag tárolóba például optikai érzékelőt kell szerelni, mellyen a megmunkálandó munkadarabok számára a programot úgy lehet módosítani, hogy a gravitációs újratöltési időt figyelembe vegye a vezérlés.

További lehetőség az operátor panel cseréje, bővítése. A jelenlegi VCP-05 HMI kis kijelzővel és memóriával rendelkezik. VCP-11-es szériától már érintőkijelzővel rendelkeznek, melyek áttekinthetőbb, könnyebb kezelést enged meg a kezelő számára. A kijelző méret a szériaszám növekedésével arányosan növekszik. A VCP-11-es típus esetén a kijelző 9,7 cm képátlóval rendelkezik.

További lehetőség az is, hogy a nyersanyag és késztermék szállítása kiváltható két futószalag alkalmazásával. A Futószalagra ömlesztve érkező nyersanyag a futószalag szélességének korlátozásával megvezethető, így pozícionálva a manipulátor számára a nyersanyagot. Ezzel a megoldással elkerülhető az ejtő tárolóban létrejövő tapadási súrlódás. Így nem jöhet létre az a hiba, hogy a nyersanyagtároló nem töltődik újra, ha az ejtő tárolóban beragad, egy munkadarab.

\section{VI. ÖSSZEFOGLALÁS}

Egy adott alkatrész gyártása során az előállítási idő nagy részét az alkatrész munkaállomások közötti szállítás teszi ki. Ennek csökkentéséhez megfelelő tereprendezés szükséges. Törekedni kell arra, hogy a különböző munkaállomások a lehető legközelebb helyezkedjenek el, így az alkatrész áthelyezésének ideje csökkenthető. Ha ezek a feltételek teljesülnek, akkor a projekt feladathoz felhasznált manipulátor képes arra, hogy az alkatrész szállítás idejét csökkentve érjek el gazdaságosabb termelést.

Projekt feladat elkészítése során sikerült a manipulátort irányító ipari eszközök között kommunikációt megvalósítani. Felkonfiguráltam a léptetőmotorokat, hogy a meghatározott, beállított pozíciókat a PLC segítségével lehessen elérni. Elkészült a vezérlés programkódja. Ehhez meg kellett ismerni a Strukturált programozási nyelvet, mivel a létra programozási nyelv a megvalósított feladathoz már bonyolult, nehezen követhető lett volna. A HMI-re különböző felületek lettek felprogramozva, melyek segítik a gép és az ember közötti kommunikációt.

Az alkatrész elkészítése a nyersanyagtárolónál kezdődik. A manipulátor a tárolóból emeli ki a munkadarabot és szállítja át az első munkafolyamatot végző állomásra. A nyersanyag tárolót gravitációs ejtő tároló tölt fel, így biztosítva a folyamatos nyersanyag utánpótlást. Az első folyamat befejezését követően a gép áthelyezi az alkatrészt 
a 2. munkaállomásra az alkatrészt és újratölti az első megmunkáló állomás tárolóját. A 2. folyamat teljesítése után az utolsó munkafolyamatot elvégző állomásra rakja át az alkatrészt és az előzőeknek megfelelően tölti vissza az üres megmunkáló állomásokat.

A projektem során különböző üzemmódok lettek kialakítva. Automata és kézi üzemmód közül lehet választani. Automata üzemmód kiválasztása esetén a gép indítástól leállításig folyamatosan szállítja az alkatrészeket a munkafázisok között emberi beavatkozás nélkül. A HMI kijelzőjén folyamatosan követhető az aktuális elkészült darabszám mennyisége, illetve az üzemidő is. Amikor a kész munkadarab mennyisége a grafikus vezérlőn megadott értéket eléri, a manipulátor felveszi a referencia pontot és megáll. Kézi üzemmód esetén a kezelő segítségével lehet irányítani a manipulátor. Meg lehet adni, hogy melyik munkaállomásról szükséges az alkatrészeket átemelni.

\section{HIVATKOZÁSOK}

[1] IclA easy Technical Documentation

[2] Rexroth IndraWorks Engineering: Operation and Programming Guide

[3] Training Manual VI-Composer

[4] PLC Programming with Rexroth IndraLogic 1.0

[5] Elektro-Pnumatikus Mozgató Rendszer Műszaki Specifikáció

[6] Varga Máté: Elektropneumatikus többtengelyes manipulátor irányítása PLC és HMI segítségével, Debreceni Egyetem, 2013

\section{KÖSZÖNETNYILVÁNÍTÁS}

A publikáció elkészítését az EFOP-3.6.1-16-2016-00022 számú projekt támogatta. A projekt az Európai Unió támogatásával, az Európai Szociális Alap társfinanszírozásával valósult meg. 